Classica et Christiana, 16/2, 2021, ISSN: 1842-3043; e-ISSN: 2393-2961, 475-493

DOI: 10.47743/CetC-2021-16.2.475

\title{
URBAN VIOLENCE IN ALEXANDRIA IN ANTIQUITY: A HISTORICAL DISTORTION?
}

\author{
Sylvain DESTEPHEN* \\ (Paris Nanterre University)
}

Keywords: violence, Alexandria, Egypt, Hellenism.

\begin{abstract}
The paper draws attention to the metropolis of Alexandria in Egypt, the third biggest city of the late Roman world. Part of recent historiography tends to look very optimistically at the late antique city as a place of religious neutrality at least until the end of the fourth Century. Far from an irenic vision of the late antique urban communities, the latest monograph on late antique Alexandria pictured the city as a place of constant conflicts between Jews, Pagans and Christians. Religion in Alexandria seems to be the main source of urban unrest. In order to measure the relevance of this position, it is necessary to examine the events seen by contemporaries as episodes of urban violence so as to understand their motivations. In order to refute the postulate that Alexandria had a rebellious tradition and that it experienced a renewal of violent tensions at the end of Antiquity, this article proposes to expand the chronological boundaries by including the Ptolemaic and Roman periods in it.
\end{abstract}

\section{Introduction}

Violence in late Antiquity has triggered many discussions among scholars and provoked a large array of articles, books, conferences; numerous lectures have dealt with it. Focusing on the history of violence is not specific to the field of late Antiquity and it discloses a general interest in a social phenomenon which seems to be increasingly singular, as the western world asserts itself as a model of civilisation which rejects violence altogether. This is not just a moral condemnation, which would allow western society to consider itself more peaceful, tolerant and civilised than previous or contemporary societies, but a real relegation of violence outside the national consensus and the social space. This widely accepted standpoint has led to a definitive

\footnotetext{
*sdesteph@parisnanterre.fr
} 
condemnation of all forms of violence, to the point where even coercive measures taken by a democratic government might be deemed illegitimate by its voters. The phenomenon of violence sparks reprobation and condemnation on the part of those commenting upon it, but both ethical values and legal provisions do not represent satisfactory or at least sufficient categories to study it in late antique society.

Compared to earlier periods, the end of Antiquity is original in that it offers an exceptional wealth of documentation, which is unfortunately often ignored or underestimated by many specialists of more classical periods. ${ }^{1}$ The purpose of this paper is not to question the exact reasons and multiple causes for this sudden abundance of texts. In fact, this phenomenon is less a late flowering of literary and documentary production, than the result of the accidental transmission or pious preservation of sources due to a more favourable situation or the particular reverence for works marked with the seal of holiness and faith. It is obvious that the strong religious flavour of several late antique sources largely explains their remarkable conservation. This is the case, for instance, for the proceedings of great or minor ecclesiastical meetings (acts of ecumenical councils, minutes of provincial synods, lists of participants, series of canons), or works written by clerics or, more rarely, monks, and later considered as Fathers of the Church (mainly spiritual or secular letters, dogmatic treatises, exegetical commentaries, homilies). It should be remembered that the patristic golden age took place in the fourth and fifth Centuries. ${ }^{2}$ Consequently, the volume and content of the mass of sources available for studying the history of the last centuries of Antiquity are dependent

${ }^{1}$ For recent overviews of late antique literature, see in particular Bernard Pouderon et alii (eds.), Histoire de la littérature grecque chrétienne, 3 vols., Paris, 2008-2017; Scott McGill and Edward J. Watts (eds.), A Companion to Late Antique Literature, New York, 2018; Fabio Gasti, Profilo storico della letteratura tardolatina (secoli III-VII d.C.), Rome, 2020; Reinhard Herzog and Peter LebrechtSchmidt (eds.), Handbuch der lateinischen Literatur der Antike, vol. 5-6 (the latter divided into two sections), Munich, 1989-2020.

${ }^{2}$ See the important synthesis edited by Angelo Di Berardino, Patrology, vol. 4: The Golden Age of Latin Patristic Literatur from the Council of Nicaea to the Council of Chalcedon, trans., Notre Dame, 2005; Michael Fiedrowicz, Handbuch der Patristik: Quellentexte zur Theologie der Kirchenväter, Freiburg/Basel/ Vienna, 2010; Claudio Moreschini, Storia del pensiero cristiano tardo-antico, Milan, 2013; Ken Parry, The Wiley Blackwell Companion to Patristics, Chichester/ Malden, 2015. 
on the inexorable conversion of the later Roman world to Christianity and the progressive confessionalization of the sources produced during this period. These two characteristics are important, not to say decisive, in the perception and interpretation that we may have of the end of Antiquity, inasmuch as the Christian sources accentuate the importance of doctrinal questions and the dimension of religious conflicts.

Under these circumstances, late Antiquity is liable to seem a little more Christian than it actually was, due to the distortion induced by the readily apologetic tone, polemical nature, religious orientation and ecclesiastical origin of most of the documents passed down to us. But my intention is not to undermine the place of Christianity in late antique society and State, still less to contest their complete conversion to the new religion. There is certainly a slight tendency in present-day historiography to secularise late Antiquity by focusing almost entirely on its administrative, military, economic or material aspects. However, no one can dispute the extent of the phenomenon of Christianisation in the later Roman Empire. Obviously, one must be careful not to overestimate the importance of doctrinal debates and the extent of religious conflicts between Christians and pagans up to the fourth Century, and then between Christians. Dogmatic controversies and religious quarrels have been the topic of much recent research because the sources related to these controversies are abundant. 3 Proceedings of Church councils and synods, imperial laws with

3 Amongst many recent publications, see Harold A. Drake et alii (eds.), Violence in Late Antiquity: Perceptions and Practices, Aldershot/Burlington 2006; Michael Gaddis, There Is No Crime for Those Who Have Christ: Religious Violence in the Christian Roman Empire, Berkeley, 2006; Maijastina Kahlos, Debate and Dialogue. Christian and Pagan Cultures c. 360-430, Aldershot, 2007; Maijastina Kahlos, Forbearance and Compulsion. The Rhetoric of Religious Tolerance and Intolerance in Late Antiquity, London, 2009; Thomas Sizgorich, Violence and Belief in Late Antiquity: Militant Devotion in Christianity and Islam, Philadelphia, 2009; Polymnia Athanassiadi, Vers la pensée unique : la montée de l'intolérance dans l'Antiquité tardive, Paris, 2010; Éric Rebillard and Claire Sotinel (eds.), Les frontières du profane dans l'Antiquité tardive, Rome, 2010; Giulia Sfameni Gasparro, Dio unico, pluralità e monarchia divina: Esperienze religiose e teologie nel mondo tardo-antico, Brescia, 2010; Marie-Françoise Baslez (ed.), Chrétiens persécuteurs : destructions, exclusions et violences religieuses au IVe siècle, Paris, 2014; Peter Van Nuffelen, Penser la tolérance durant l'Antiquité tardive, Paris, 2018; Jitse H. F. Dijkstra and Christian R. Raschle (eds.), Religious Violence in the Ancient World: from classical Athens to late Antiquity, Cambridge, 2020. 
doctrinal or disciplinary content, episcopal homilies, dogmatic or polemical treatises and ecclesiastical histories were written in the context of and explained in the light of religious conflicts. The sectarian animosity and the fierce antagonisms that run through many of these texts suggest strong religious tensions and crises that late antique sources evoke at length because they were religiously oriented. For these reasons, the place of religious conflicts and religious intolerance in late antique studies takes on a singular significance in comparison with earlier periods, to the extent that religion seems to be the primary cause of political unrest and the main source of social tension. This documentary and historiographical distortion has resulted in a steady stream of scholarship on religious issues and, more recently, on religious violence presented as a prominent feature of the later Roman Empire.

Instead of taking a position in this scholarly debate, I have chosen to draw attention to the urban world, in particular the metropolis of Alexandria in Egypt, the third biggest city of the late Roman world after the twin capitals, Rome and Constantinople. This geographical reorientation makes it possible to shift both the gaze and debate towards a singular framework, since part of recent historiography, partly inspired by the seminal work of Claude Lepelley and Robert Markus, tends to look very optimistically at the late antique city as a place of open debate, religious neutrality, and unexpected secularism, at least until the end of the fourth Century. The works which defend (or more rarely refute) these positions mainly deal with the western half of the Roman Empire and, to a lesser extent, the eastern part, with the notable exception of the city of Antioch.4 Far from an excessively irenic vision of the late antique urban communities, the

4 Johannes Hahn (ed.), Gewalt und religiöser Konflikt: Studien zu den Auseinandersetzungen zwischen Christen, Heiden und Juden im Osten des Römischen Reiches (von Konstantin bis Theodosius II.), Berlin, 2004; Emmanuel Soler, Le sacré et le salut à Antioche au IVe siècle: pratiques festives et comportements religieux dans le processus de christianisation de la cité, Beyrouth, 2006; Isabella Sandwell, Religious Identity in Late Antiquity: Greeks, Jews, and Christians in Antioch, Cambridge, 2007; Brent D. Shaw, Sacred Violence: African Christians and Sectarian Hatred in the Age of Augustine, Cambridge, 2011; Christine Shepardson, Controlling Contested Places: Late Antique Antioch and the Spatial Politics of Religious Controversy, Berkeley, 2014; Retorica, scuola, religioni ad Antiochia (IV-V sec. d.C.), Rome, 2015; Jan R. Stenger, Johannes Chrysostomos und die Christianisierung der Polis: 'Damit die Städte Städte werden', Tübingen, 2019. 
latest monograph on late antique Alexandria, published in 1997, pictured the city as a place of serious and constant conflicts between Jews, Pagans and Christians. 5 The issue of the troubles in late antique Alexandria were related to religious affiliations and not caused by ethnicity, social groups or professional categories. Religion in Alexandria, particularly Christianity, seems to be the main, if not the only, source of urban unrest. In order to measure the relevance of this position, it is necessary to examine the events seen by contemporaries as episodes of urban violence so as to understand their motivations and to measure their intensity. In order to ascertain or refute the double postulate that Alexandria had a rebellious tradition and that it experienced a renewal of violent tensions at the end of Antiquity, this article proposes to expand the chronological boundaries by including the Ptolemaic and Roman periods in it.

\section{Violence in late antique Alexandria: epiphenomenon or epicentre?}

As violence is a subjective concept its perception and magnitude depend on a mobile scale of personal and cultural values, and therefore it is difficult, if not impossible, to quantify in any statistical way the acts considered violent in the urban space. Although late antique sources are abundant compared to the sources of earlier periods, they do not offer a systematic and categorical recording of crimes and offences committed in Alexandria at the end of Antiquity. For this reason, the perception of violence in the urban space depends on the testimony of contemporary authors, in many cases foreigners who actually did not live there. It should be remembered that the main historians of late Antiquity whose writings have been preserved were in fact alien to Alexandria and even to Egypt. The exception would be the historian Olympiodorus of Thebes, who nevertheless made a career in Constantinople, working in the Emperor Theodosius II's diplomatic service in the first two decades of the fifth Century. ${ }^{6}$ As a re-

5 Christopher Haas, Alexandria in Late Antiquity: Topography and Social Conflict, Baltimore, 1997, reprint. 2006. See also the more recent and briefer monographic study of Edward J. Watts, Riot in Alexandria: Tradition and Group Dynamics in Late Antique Pagan and Christian Communities, Berkeley, 2010.

${ }^{6}$ See Andrew Gillett, The Date and Circumstances of Olympiodorus of Thebes, Traditio, 48, 1993, 1-29; Antonio Baldini, Ricerche di tarda storiografia 
sult, the narrative sources that mention Alexandria were most often written outside the city, if not the province itself. The exterior view of the metropolis and its region was influenced, as it is for any historian, by the social and cultural environment in which the writers lived. Thus, the almost synoptic Church historians of the fifth Century (Socrates Scholasticus, Sozomen and Theodoret of Cyrrhus) as well as their contemporaries and continuators of the fifth and sixth Centuries (Rufinus, Philostorgius, Theodorus Lector, Evagrius Scholasticus) composed historical narratives heavily dominated by dogmatic debates and ecclesiastical affairs. Alexandria was perceived less as a city than as the seat of an important but tumultuous Christian community, divided between antagonistic confessions and led by bishops whose disciplinary and dogmatic authority, and even personal character, were not the subject of nuanced portraits. 7

At the same time, the partisan character of the Christian historiography of the later Roman Empire had serious consequences on the image of Alexandria or rather on the image of the city's leaders. Consequently, it is necessary and also prudent to avoid writing an urban history of Alexandria which would rely only upon late antique, literary sources. Their high degree of personalisation appears both in

da Olimpiodoro di Tebe, Bologne, 2004; Warren Treadgold, The Diplomatic Career and Historical Work of Olympiodorus of Thebes, IHR, 26, 2004, 709-733; Peter Van Nuffelen, Olympiodorus of Thebes and eastern triumphalism, in Christopher Kelly (ed.), Theodosius II: Rethinking the Roman Empire in Late Antiquity, Cambridge, 2013, 130-152; Timo Stickler, Das Geschichtswerk des Olympiodor von Theben, in Bruno Bleckmann and Timo Stickler (eds.), Griechische Profanhistoriker des fünften nachchristlichen Jahrhunderts, Stuttgart, 2014, 85-102.

7 Here is the list of the main relevant passages dealing with Alexandria, its inhabitants, religious communities and leaders (mostly bishops) in late Antiquity: Socrates Scholasticus, I, 5-6; I, 9; I, 23; I, 27; II, 3; II, 11; II, 14; II, 23; II, 26; II, 28; III, 2-4; III, 7-8; III, 14; IV, 13; IV, 20-22; IV, 24-25; IV, 37; V, 16-17; VI, 9-10; VII, 7; VII, 13-15. Sozomen, I, 15-16; I, 24-25; II, 17-18; II, 22-23; II, 25; II, 31; III, 6; III, 9; III, 15; III, 20-21; IV, 2; IV, 9-10; V, 6-7; V, 12-14; VI, 5; VI, 19; VI, 25; VII, 15; VII, 19-20; VIII, 2; VIII, 11; VIII, 19-20; VIII, 24. Theodoret of Cyrrhus, HE, III, 4; III, 9; IV, 2; IV, 20; IV, 22-23; IV, 28; IV, 30; V, 23; V, 37. Rufinus, HE, X, 1; X, 1215; X, 20; X, 24; X, 29-30; XI, 3-4; XI, 6-7; XI, 20-26; XI, 28-30. Philostorgius, I, praef.; I, 3-4; II, 7; II, 11; III, 3; III, 12; VII, 2; VIII, 9-10. Theodorus Lector, epitome, ed. Hansen, $23 ; 39-43 ; 53 ; 59 ; 61 ; 63 ; 66 ; 79-80 ; 99 ; 130 ; 160 ; 265 ; 368-371$; 379-380; 403-404; 409; 416-417; 423-425; 427-428. Evagrius Scholasticus, I, 3; I, 6; I, 10; II, 4-5; II, 8-11; II, 18b; III, 4-6; III, 11-13; III, 15; III, 17-18; III, 22-23; IV, 11; IV, 37; V, 16. 
the subjectivity that each author inserted into his historical narrative and also in the focus on individuals rather than on groups, movements or institutions. The history of the Roman Empire is often reduced to the history of the conflictual or harmonious relations between rulers and members of the Senate in Rome, as recorded via the reed pens of authors such as Appian, Cassius Dio or Herodian, all active in the second and third Centuries. Forming an anonymous and shadowy group, the rest of Roman society seems to gravitate silently and reverently around emperors and senators. ${ }^{8}$ In the same way, the history of late antique Alexandria is dominated from very high up by the action of some remarkable protagonists, first of all the leaders of local religious communities and, in the background, local representatives of the imperial power. Due to this historiographical prism, urban, disruptive phenomena were frequently interpreted in Antiquity as a reaction to decisions made by a very few people who embodied collective actions and unleashed communitarian violence. For this reason, the disturbances which could throw into turmoil an ancient megalopolis such as Alexandria were inevitably associated by ancient authors with a small number of instigators, plotters and protagonists, who were identified and sometimes blamed when their actions challenged political of religious order. The violent phenomena that occurred in Alexandria were not necessarily large-scale events, far from it, and were often amplified and simplified by the sources for some ideological reason. However, when these dramatic events were the subject of a structured narrative, they were generally associated with individuals who allegedly led or aroused anonymous, aggressive groups or brutal crowds. 9

8 On the historiography of the Roman High Empire, embodied by these three Greek-speaking historians, see Martin Hose, Erneuerung der Vergangenheit: die Historiker im Imperium Romanum von Florus bis Cassius Dio, Stuttgart/ Leipzig, 1994; Fergus Millar, A Study of Cassius Dio, Oxford, reprint. 1999; Barbara Kuhn-Chen, Geschichtskonzeptionen griechischer Historiker im 2. und 3. Jahrhundert n. Chr. Untersuchungen zu den Werken von Appian, Cassius Dio und Herodian, Frankfurt, 2002; Josiah Osgood, Breviarium totius imperii: the background of Appian's Roman History, in Kathryn Welch (ed.), Appian's Roman History: Empire and Civil War, Swansea, 2005, 23-44.

9 Several studies have been recently dedicated to the historiographical (mis)representation of violence in late antique Alexandria: Troels Myrup Kristensen, Religious Conflict in Late Antique Alexandria: Christian Responses to 'Pagan' Statues in the Fourth and Fifth Centuries, in George Hinge and Jens A. Krasilnikoff 
The strong personalisation of secular and ecclesiastical history in Antiquity explains why the episodes of violence, which tormented Alexandria with a frequency that is actually impossible to determine, took the form of actions directed against individuals rather than groups or institutions. Unsurprisingly, the best documented outbursts of violence in the urban history of late antique Alexandria were presented by the ancient authors as conflicts of persons or rivalries between protagonists. An individual hatred, which according to the sources was not reciprocal, set bishop Cyril of Alexandria, or more probably part of his clergy mixed with devout (or fanatic) laymen, against the Neoplatonist philosopher Hypatia. Another deadly rivalry pitted the Monophysite bishop Timothy Aelurus against Proterius, his Chalcedonian successor. These asymmetrical personal hostilities, attested in the second case, certainly fictitious in the first, ended with the murder of Hypatia in 415 and that of Proterius in 457. In both cases, although the victims belonged to distinct religious communities, their murder was carried out in the same atrocious way: their bodies were lacerated, dismembered, thrown out of the urban space and eventually burnt. The similarity of the ignominious treatment inflicted upon both the philosopher and bishop's bodies demonstrates a form of ritualised, almost staged violence, which had already occurred in 361 with the murder of a former bishop of Alexandria, namely George of Cappadocia. ${ }^{10}$ These peaks of violence were directed at public figures who were emblematic of an intellectual or doctrinal current that diverged from a part of the population of Alexandria. In 415 and 457, although the murders committed were not accompanied by

(eds.), Alexandria: A Cultural and Religious Melting Pot, Aarhus, 2009, 158-175; Clelia Martínez Maza, Religious Conflict in Late Antique Egypt: urban and rural contexts, in David Hernández de la Fuente (ed.), New Perspectives on Late Antiquity, Newcastle, 2011, 48-63; Alberto Camplani, The religious identity of Alexandria in some ecclesiastical histories of Late Antique Egypt, in Philippe Blaudeau and Peter Van Nuffelen (eds.), L'historiographie tardo-antique et la transmission des savoirs, Berlin, 2015, 85-119; Jitse H. F. Dijkstra, Religious Violence in Late Antique Egypt Reconsidered: the cases of Alexandria, Panopolis and Philae, JECH, 5, 2015, 24-48.

${ }_{10}$ Most of the information on the murder of Bishop George de Cappadocia is provided by Gregory of Nazianzus, Oration, 21, 26; Ammianus Marcellinus, XXII, 11, 8-10; Historia Acephala, 2, 9; Epiphanius of Salamis, Panarion, 68 and 76; Jerome, Chronicle, a. 362; Socrates Scholasticus, III, 2; Sozomen, V, 7; Philostorgius, VII, 2; Theodoret of Cyrrhus, HE, II, 14; Chronicon Paschale, a. 362. 
serious urban unrest, they nevertheless constituted the two moments of violence that are best attested by the sources. Whilst Hypatia's murder featured mostly in Greek sources, Proterius' assassination had a far greater impact, to the point of being also mentioned in the Latin and Byzantine sources. ${ }^{11}$ However, modern bibliography has paid much more attention to the female philosopher than to the male Church leader. ${ }^{12}$ Far from suggesting that violence in Alexandria was a frequent or episodic phenomenon, the historiographical echo of Hypatia and Proterius' murders clearly shows the personalised bias and

${ }^{11}$ Here are listed the main sources dealing with Hypatia's murder: Synesius of Cyrene, Ep., X; Rufinus, HE, XI, 23; Socrates Scholasticus, VII, 15; Philostorgius, VIII, 9; Damascius, Vita Isidori, frgs. 102 and 276; Hesychius Illustrius, frg. 7; Theodorus Lector, epitome, 311; John Malalas, XIV, 12; Cassiodorus, Historia tripartita, XI, 11; John of Nikiu, 84; Theophanes, ed. de Boor, 82, l. 16; Suidas, Y 166 (it makes an unparalleled connection with Proterius' murder); Nicephorus Gregoras, Historia romana, ed. Bekker, vol. 1, 294; Nicephorus Callistus, HE, XIV, 16. On Proterius' murder, see Gennadius of Marseille, De viris illustribus, 73; Victor of Tunnuna, a. 457; Zachariah Rhetor, HE, IV, 5; Evagrius Scholasticus, II, 8; Theodorus Lector, epitome, 368-369; Cyril of Scythopolis, Vita Euthymii, 32; Germanus of Constantinople, On Heresies and Synods, 27; Theophanes, ed. de Boor, 107, 110, 111; Synodicon Vetus, 93; Synaxarium of Constantinople, Februar 28th; Cedrenus, ed. Bekker, vol. 1, 608-609; George Monachus, $P G$, 110, col. 789; Theodorus Scutariotes, Chronicle, II, 138; Nicephorus Callistus, $H E$, XV, 16-17.

12 On Hypatia's murder, see Sarolta Anna Takács, Hypatia's Murder: The Sacrifice of a Virgin and Its Implications, in Katharine B. Free (ed.), The Formulation of Christianity by Conflict Through Ages, New York, 1995, 47-62; Maria Dzielska, Hypatia of Alexandria, Cambridge (Ma), 1995, 83-100; Haas, Alexandria in Late Antiquity, 313-315; Edward J. Watts, The Murder of Hypatia: Acceptable or Unacceptable Violence?, in Harold A. Drake et alii (eds.), Violence in Late Antiquity, 333-342; Alan Cameron, The Life, Work and Death of Hypatia, in Delphine Lauritzen and Michel Tardieu (eds.), Le voyage des légendes. Hommages à Pierre Chuvin, Paris, 2013, 65-82; Edward J. Watts, Hypatia: The Life and Legend of an Ancient Philosopher, Oxford, 2017, 107-120; Silvia Ronchey, Morte accidentale di una professoressa. In margine a un recente libro su Ipazia, Medioevo greco, 18, 2018, 351-371; Mareile Haase, The Shattered Icon: An Alternative Reading of Hypatia's Killing (Socrates, Hist. eccl. 7.15.5-7, John of Nikiu, Chron. 84.100-103, and Rufinus, Hist. eccl. 11.23), in Dawn LaValle Norman and Alex Petkas (eds.), Hypatia of Alexandria. Her Context and Legacy, Tübingen, 2020, 87-117; eadem, Hypatia's Death According to Socrates, Hist. eccl. 7.15: A Textual Commentary, ibidem, 255-284. On Proterius' murder, see Philippe Blaudeau, Alexandrie et Constantinople (451-491): de l'histoire à la géo-ecclésiologie, Paris, 2006, 148-153; Alfredo Bronzato da Costa Cruz, A tragédia do patriarca Protério de Alexandria (451-458): Disputas teológico-eclesiásticas e violência no Egito tardo-antigo, Revista Poder \& Cultura, 3, 2016, 60-100, part. 79-81. 
religious character of late antique literary sources, which preferably focused on the terrible fate of remarkable individuals rather than on collective movements. The same historiographical inclination to personalise dramatic events could also explain why the destruction of the great temple of Serapis in Alexandria, a moment of collective violence in 391, was simplistically transformed by some imaginative Christian authors into a duel between Bishop Theophilus and Olympius, a zealous pagan philosopher with a suitably programmatic name to illustrate the final defeat and overthrow of paganism by Christianity. ${ }^{13}$

\section{Violence in Roman Alexandria: a public and iniqui- tous prerogative?}

From a comparative perspective, it might be useful to consider the extent of violence in Alexandria in the periods prior to late Antiquity in order to determine whether urban violence constituted a social constant or a historical feature. For the period of the High Roman Empire, we rely upon sources that are mainly narrative, and which thus ignore everyday violence or ordinary crimes and focus on political accidents and natural disasters. For instance, in the early third Century, the most memorable event was not a riot or an insurrection, but a bloodbath committed by soldiers accompanying Emperor Caracalla during his stay in Alexandria in 215, that led to later clashes between supporters and opponents of Caracalla's successors to the throne. ${ }^{14}$ The circumstances surrounding both events are obscured by the hostility of ancient historians against Caracalla, such as Cassius Dio, Herodian and the Historia Augusta's anonymous author. 15 They offer

${ }^{13}$ On Olympius, see his prosopographical entry in $\mathrm{Dpa}$, IV, 772-773, by Stéphane Diebler.

14 David S. Potter, The Roman Empire at Bay, AD 180-395, London/New York, 2004, 143-144; Agnès Bérenger-Badel, Caracalla et le massacre des Alexandrins: entre histoire et légende noire, in David El Kenz (ed.), Le massacre, objet d'histoire, Paris, 2005, 121-139; Steffan Pfeiffer, Der römische Kaiser und das Land am Nil. Kaiserverehrung und Kaiserkult in Alexandria und Ägypten von Augustus bis Caracalla (3O v. Chr.-217 n. Chr.), Stuttgart, 2010, 202-205.

${ }_{15}$ Evidence is given by Cassius Dio, LXXVIII, 22-23; Herodian, IV, 9; Historia Augusta, Caracalla, VI, 2-3. Surprisingly, the fictitious nature of this event was defended by Frank Kolb, Literarische Beziehungen zwischen Cassius Dio, Herodian und der Historia Augusta, Bonn, 1972, 111-115. However, this opinion is still very much in the minority in present-day historiography, especially since papyrus 
discordant narratives which, moreover, suffer from internal contradictions. Nevertheless, it should be noted that these rare explosions of violence were of a political and not religious nature, unlike the cases attested in late Antiquity. The presence of the emperor in Alexandria in 215 and the weakening of imperial power in 217 seem to have acted as a catalyst to resistant movement plotting against the Roman authorities. In fact, ancient historians simplified the chronological framework and recomposed the succession of events to make Alexandrians the innocent victims of Roman representatives' abuses.

Victimisation barely concealed the staunch hostility of part of the Alexandrian population to Roman rule. Evidence of such hostility can be found in a curious collection of papyri known as the Acta Alexandrinorum or Acts of the Pagan Martyrs that came to light in the nineteenth Century. Although the title is sanctioned by scholarly tradition, it is well known that the name was totally inappropriate, since it draws a misleading parallel with the Passions of the Christian martyrs, whose motivations were strictly religious and not political. On the other hand, the Acts of the Pagan Martyrs constitute a literature of political self-defense and communitarian propaganda in the form of a dozen disparate texts written between the beginning of the first and the beginning of the third Centuries, bringing leading citizens of Alexandria into conflict with Roman rulers (emperors, governors). ${ }^{16}$

records attest to the execution of members of the municipal elite and long trials. See Kostas Buraselis, Zu Caracallas Strafmaßnahmen in Alexandrien (215/6). Die Frage der Leinenweber in P. Giss. 40 II und der syssitia in Cass. Dio 77 (78). 23.3, ZPE, 108, 1995, 166-188; Chris Rodriguez, Caracalla et les Alexandrins: coup de folie ou sanction légale?, JJP, 42, 2012, 229-272 ; Patrick Reinard, Gaias Rechtsstreit und Caracallas Alexandria-Aufenthalt. Zum Kontext des Privatbriefs P.Oxy. 43/3094, $S A A, 21,2016,209-219$.

${ }_{16}$ The whole collection of papyri was first edited with a commentary by Herbert A. Musurillo, The Acts of the Pagan Martyrs: Acta Alexandrinorum, Oxford, 1954. This remarkable collection has triggered several studies. See in particular Andrew Harker, Loyalty and Dissidence in Roman Egypt: the case of the Acta Alexandrinorum, Cambridge, 2008; Andreas Hartmann, Judenhass und Märtyrertum. Zum kulturgeschichtlichen Kontext der Acta Alexandrinorum, in Andreas Hartmann and Gregor Weber (eds.), Zwischen Antike und Moderne: Festschrift für Jürgen Malitz zum 65. Geburtstag, Speyer, 2012, 119-209; Nikoletta Kanavou and Amphilochios Papathomas, An Alexandrian Murder Case Revisited (P. Philammon = BGU IV 1024), pp. 6.3-8.21), ZPE, 200, 2016, 453-469; Livia Capponi, Trajan dans les Acta Alexandrinorum: un portrait contradictoire?, in Stéphane Benoist et alii (eds.), Mémoires de Trajan, Mémoires d'Hadrien, Villeneuve d'Ascq, 
The violence is here the prerogative of the latter, who are accused of trying, condemning and executing distinguished and innocent inhabitants of the Egyptian metropolis. These figures, presented as resistance fighters against Roman oppression, were all members of the city's Greek community and pretended to oppose the greed, arrogance, brutality and immorality of Roman rulers. Whilst in late Antiquity, Alexandria would have been disturbed by outbreaks of violence caused only by religious conflicts, during the High Roman Empire, violence would have been only political. It is worth noting that, in both periods, violence was directed against individuals rather than groups, with the exception of the massacres ordered by Caracalla, who was portrayed as a bloodthirsty despot. The small number of Acts of the Pagan Martyrs shows that the violence actually took the form of punctual and judiciary repression. However, the accounts of the events of 215 and the concocted court minutes both served to denounce the arbitrary nature of the Roman authorities. Although they defended different interests, authors who narrated the massacres of 215 and those who forged judicial reports were actually motivated by the same desire to denounce Roman rulers, episodically in the case of the historians hostile to Emperor Caracalla, and more systematically in the Acts of the Pagan Martyrs.

Legally and politically, from the standpoint of the Roman authorities, State violence, whether it be in the form of arrests, trials and executions or military intervention, was indispensable when an effective, local police force was lacking. Consequently, for any Roman ruler worth his salt, violence was a just and necessary response to the insubordination or rebellion of populations subject to Rome. However, the sources reporting these events took a radically different view in order to deprive such interventions of any justification and completely discredit the Roman authorities responsible for them. Insofar as the legitimacy of power was judged by the ancient authors according to moral criteria and social customs, the right to exercise lawful violence in public space was justified only if rulers defended civic order, secured individuals and protected property. Yet the forgers of the Acts of the Pagan Martyrs, who were vehement supporters of a fierce

2020, 187-204. Take note of the still unpublished thesis defended by Chris Rodriguez, Les procès des Acta Alexandrinorum: une vision des vaincus sur les relations entre Alexandrie et Rome aux deux premiers siècles de notre ère, Université Paris 1 Panthéon Sorbonne, 2017. 
Hellenism that was hostile to Jews and Romans alike, and the historians of the High Roman Empire, who definitively tarnished a former emperor's memory, both deliberately presented governors and the Emperor Caracalla as a threat to civil peace, physical integrity and the right to property. To this end, judicial and military repression was portrayed as blind and relentless violence, a violence that threatened the Alexandrian's political autonomy (partial elimination of the local elite), that harmed bodies (tortures and executions,) and that placed property in peril (confiscation and destruction). Such sources suggested that the Roman authorities took arbitrary decisions and used unjustified violence because they were clearly driven by feelings unworthy of virtuous rulers. For this reason, the Acts of the Pagan Martyrs evoked the depravity and greed of governors, whilst historians pointed to the pusillanimity and cruelty of the Emperor Caracalla. The violence that suddenly afflicted the Egyptian metropolis and its ruling class was presented by ancient authors, and understood by ancient readers, as an ultimate manifestation of tyranny. ${ }^{17}$

It is easy to understand how partisan narratives and polemical accounts deliberately omitted the precise context of such events, since the context showed how the Roman authorities did not have the initiative nor the monopoly on violence: the Romans intervened in a reactive rather than in a proactive manner. The historians hostile to $\mathrm{Ca}-$ racalla and the falsifiers of judicial decisions concealed the deep-rooted causes of the force displayed by Roman authorities in order to deprive it (and them) of any justification. However, a close reading of the sources proves that Roman State violence was clearly more a reaction than an intervention. In the case of the massacres of 215 , victims were city officials sent to embassies to greet the emperor and young men who attended an official ceremony in the gymnasium of Alexandria. Both groups belonged to the Greek, local elite and some of them were probably arrested, tried and executed for having torn down statues erected in honour of the emperor, perhaps to protest against contributions to his forthcoming military campaign against the Parthians. ${ }^{18}$ Moreover, since their edition by Herbert Musurillo, the Acts of the Pagan Martyrs struck readers and scholars with the re-

${ }_{17}$ Musurillo, The Acts of the Pagan Martyrs, passim.

${ }_{18}$ Cassius Dio, LXXVIII, 22; Herodian, IV, 9. On the other hand, Historia Augusta, Caracalla, VI, 2-3, provides a very neutral, almost flat, record of the same events. 
current criticism of Roman rule, its support for the Alexandrian Jews and the ferocious hostility of a part of the Greek community against them. Thus, the real reasons behind the Roman authorities' decision to judicially and military intervene were primarily Greek virulent anti-Judaism, the latter already attested by Philo of Alexandria and Josephus in the first Century, coupled with an Alexandrian anti-fiscal revolt. ${ }^{19}$ In other words, urban violence in Alexandria during the High Roman Empire was induced by the privileged part of its population, even though partial sources tried to conceal it. Due to this distortion of the evidence, violent events recorded during this period seem to differ from the disturbances which affected Alexandria in late Antiquity. During the High Roman Empire, despite the narrative manipulations of local sources and ancient historians, urban violence mostly resulted from inter-communal conflicts, of an ethnic and non-religious nature, or from anti-fiscal revolts leading to a judicial and military response from the authorities. ${ }^{20}$ On the other hand, during the Later Roman Empire, personal rivalries and religious opposition would explain the outbreaks of violence. In both periods, urban violence seems punctual, but the dissimilarity of the motivations is quite surprising, since Alexandrian society did not undergo any profound changes. Should we suppose that the different nature of the sources of the High Roman Empire and of late Antiquity would explain the distinct nature of the violence recorded in Alexandria?

\section{Violence in Hellenistic Alexandria: a political demon- stration?}

In order to confirm or deny this hypothesis, it might be interesting to look at the earliest period in the history of the Egyptian metropolis, the Ptolemaic period. Founded in $331 \mathrm{BC}$ on the site of a fi-

\footnotetext{
19 I refer to the treaties of Philo of Alexandria, Legatio ad Gaium, and Josephus, Contra Apionem. See also Harker, Loyalty and Dissidence in Roman Egypt, 9-47; Hartmann, Judenhass und Märtyrertum, 127-146; Chris Rodriguez, Les Acta Isidori: Un procès pénal devant l'Empereur Claude, RHDFE, 88, 2010, 1-41, in particular 33-38.

${ }^{20}$ Harker, Loyalty and Dissidence in Roman Egypt, 48-98; Hartmann, Judenhass und Märtyrertum, 148-152; Ari Bryen, Martyrdom, Rhetoric, and the Politics of Procedure, Classical Antiquity, 33, 2014, 243-280, in particular 269-272; Kanavou and Papathomas, An Alexandrian Murder Case Revisited, 465; Capponi, Trajan dans les Acta Alexandrinorum, 200-201.
} 
shing village, Alexandria developed rather slowly for half a century before being promoted as a capital by Ptolemy II Philadelphus (r. 283$246 \mathrm{BC}$ ). Despite this promotion, which was accompanied by a demographic, intellectual, monumental and commercial boom, few local sources have come down to us. The scarcity of sources led the British historian Peter M. Fraser, author of a monumental history of Hellenistic Alexandria, to assume that the capital of the Ptolemaic kingdom in the third Century $\mathrm{BC}$ experienced a kind of political idyll, to use a term cherished by Alexandrian poets. ${ }^{21}$ The reality becomes a little less flattering perhaps when the sources start to proliferate. In fact, the documentary situation improved considerably from the following century onwards, thanks in particular to the information provided by contemporary historians from the later Hellenistic period, foremost Polybius. It was precisely from the second Century BC onwards that crises of violence arose at Alexandria. The German historian Peter Franz Mittag, in an illuminating article on the Alexandrian civil disorder in the Hellenistic period, carefully examined each episode of urban upheaval. He has listed sixteen urban riots that took place over a period of approximately 120 years, from the disturbances caused by Ptolemy VI Philometor's advent in 169 BC to the uprising of the inhabitants during the stay of Julius Caesar in 46 BC. ${ }^{22}$

According to Polybius and his followers, imitators or successors, such as Diodorus Siculus, Pompey Trogue (known through Justin's epitome), Livy and Cassius Dio, moments of violence in Hellenistic Alexandria corresponded to civil disorder, popular insurrections, and

${ }^{21}$ Peter M. Fraser, Ptolemaic Alexandria, vol. 1, Oxford, 1972, 130-131. The agitated period has also been related to the end of the Hellenistic period by Günther Hölbl, A History of the Ptolemaic Empire, trans., London/New York, 2001, 210-211. On the other hand, the crisis of the Ptolemaic monarchy has been dated to the turn of the second Century BC by Werner Huss, Ägypten in hellenistischer Zeit 332-30 v. Chr., Munich, 2001, 473ff.

22 Peter Franz Mittag, Unruhen im hellenistischen Alexandreia, Historia, 52, 2003, 161-208. See also the pioneering paper of William Barry, The Crowd of Ptolemaic Alexandria and the Riot of 203 B.C., EMC, 37, 1993, 415-431. Least but no last, one shall mention the unpublished thesis of Richard A. Todd, Popular Violence and Internal Security in Hellenistic Alexandria, University of California, Berkeley Ph.D., 1963. A positive assessment of it has been made by Mittag, Unruhen, 166-167. 
urban riots. ${ }^{23}$ Unlike the violent events that occurred in late Antiquity and the High Roman Empire, outbursts of violence mentioned at the end of the Ptolemaic period did not seem to have any particular religious, communal or fiscal dimension. The urban violence that affected Alexandria during the Hellenistic period was perpetrated by the local population or rather the more motley element of it. There was no main actor, no political leader accused of arbitrariness and cruelty or a religious leader guilty of murder, rather a series of private individuals or mercenaries, both of which were abhorred by the ancient authors who belonged to the ruling class and were stuck to its values. Those responsible for urban unrest are most often depicted as anonymous, versatile, disruptive groups: civilians or soldiers with unreasonable feelings, unbridled passions and despicable motives. Witnessing the decline of the Hellenistic kingdoms and the rise or apogee of the Roman Empire, ancient historians fully and heartly condemned the violence that troubled Alexandria without, however, supporting the local dynasty. Focusing on previous rulers, who were assessed according to their vices and virtues, Hellenistic and Graeco-Roman historians interpreted popular emotions of Alexandria as manifestations of the crisis of a monarchy they despised and condemned altogether. According to Polybius and his successors, as the Ptolemaic kingdom entered the orbit and then submitted to the vassalage of Rome, violent crises seemed to multiply. Imitating the example of Polybius, who visited Alexandria in $139 \mathrm{BC}$, the ancient historians were keen to paint the city in a very dark light. Indeed, in order to enhance the moral, political and military superiority of the Greeks over the Egyptians, but also of the Romans over the Greeks themselves, the authors

${ }^{23}$ Here is the list of the most relevant sources dealing with urban riots in Hellenistic Alexandria: Polybius, XV, 25-33; Cicero, Pro Rabirio Postumo, 4; Caesar, Bellum civile, 3, 106; Diodorus Siculus, I, 83, 8-9; XXXI, 15a; XXXI, 18; XXXIII, 6, 12 and 23; XXXIV-XXXV, 14 and 20; Pompey Trogue, prol., 38-40; Livy, XLV, 11; periochae XLVI, 9; XLVII, 6; LIX, 14; Strabo, XVII, 11; Justin, XXXVIII, 8, 4 and 12; XXXIX, 3, 2; XXXIX, 4, 1; Josephus, Contra Apionem, II, 50; Appian, Bellum civile, I, 102; Pausanias, I, 9, 1-3; Cassius Dio, XXXIX, 12-15 and 58; XLII, 35-42. All these Alexandrine riots have been mentioned and commented in more or less detail, depending on the richness of the available sources, by Hölbl, A History of the Ptolemaic Empire, passim, and Huss, Ägypten in hellenistischer Zeit, passim. 
described Alexandria as an ungovernable metropolis that was inhabited by a disorderly and violent population. ${ }^{24}$

However, the detailed analysis of historical sources carried out by P. F. Mittag reveals a reality which, as in the High Roman Empire and late Antiquity, does not always correspond to the message that the ancient authors were trying to convey. Far from showing an inexorable weakening of Ptolemaic Egypt, that was riven by internal dissension, episodic outbreaks of urban violence appear to have had other root causes: threats to the integrity of the kingdom itself (transfer or loss of territory or income) or to the transmission and exercise of power within the Ptolemaic dynasty (uncertain succession, undesirable advent, unpopular marriage, shocking personal behaviour). ${ }^{25}$ The violence in Alexandria during the Hellenistic period thus had a dimension that was undeniably political, even more so than in the High Roman Empire. The political grievances were also combined with tensions between communities and the demands of the local elite in terms of institutions (creation of a local council) or taxation (tax reduction or fiscal stability). When one examines the outbreak and use of violence in Alexandria throughout Antiquity, a parallel springs to mind, almost an intangible one: although violence has always been condemned by ancient authors, violence was occasionally used by the rulers themselves. In late Antiquity, authoritarian and ambitious bishops of Alexandria encouraged their most fervent or fanatical supporters to physically rid the city of the defilement caused by religious opponents. During the High Roman Empire, according to biased sources, urban violence was used at the expense of distinguished members of the Greek community and embodied by governors or emperors unworthy of the office they held. For the Hellenistic period, although historical sources placed greater emphasis on the political or dynastic significance of riots, which sometimes descended into bloodshed, the concomitance between violent episodes, actions of the palace guards and divisions within the Ptolemaic dynasty suggests that the rioters or mutineers were manipulated by relatives of the king or officers of the guard. For example, the uprising that led in 132/131 BC to the partial burning of the royal palace in Alexandria and the expul-

24 This famous visit is mentioned by Polybius, XXXIV, 14, 1-8, but actually known through Strabo, XVII, 12.

25 Mittag, Unruhen, 193-203. 
sion of Ptolemy VIII Euergetes II, discredited by the murders he had ordered within his own lineage, was fermented by his sister and first wife, Cleopatra II. ${ }^{26}$

In the historical narratives of ancient authors who were always hostile to the Alexandrian mob and the Ptolemaic kings as well, urban violence took actually the unexpected form of a radical and collective political action to restore respectability and ensure the continuity of the same dynasty whose legitimacy was never questioned, and monarchical power never contested. In a sense, urban popular violence in Alexandria, whether spontaneous or manipulated, was reactionary and not revolutionary. On the other hand, due to their social bias or ideological blindness, in the ancient historians' gaze, the violent and sudden intrusion of the mob into influencing the designation, revocation or elimination of their own kings (and sometimes queens) proved both the incapacity of the latter to govern the capital and, more generally, the incompetence of the entire Ptolemaic dynasty. Consequently, episodes of violence in Hellenistic Alexandria took on different dimensions, depending on whether one adopts the point of view of anonymous rioters, agents provocateurs belonging to the royal family and guard, or Greek and Roman historians.

\section{Conchsion}

At the end of this brief survey, it appears that urban violence in Alexandria was unsurprisingly an old phenomenon. However, this does not confirm the negative image forged in the second Century BC by the historian Polybius and repeated by the orator Dio Chrysostom three centuries later of a city irremediably rebellious, whose cosmopolitan character would be the primary cause of its irascible and uncontrollable population. An overview of the moments of violence over a millennium, from the founding of the city by Alexander to its conquest by the Arabs, shows that urban unrest remained occasional and limited in time. Under these conditions, the violence of the Egyptian metropolis in Antiquity would be more an episodic than an idiosyncratic phenomenon. In spite of different expressions and varied moti-

${ }^{26}$ The main evidence is furnished by Diodorus Siculus, XXXIII, 6, 12 and 23; Livy, periochae, XLIX, 14; Justin, XXXVIII, 8, 11. See also comments in Hölbl, A History of the Ptolemaic Empire, 197-198; Huss, Ägypten in hellenistischer Zeit, 608-611; Mittag, Unruhen, 179-180. 
vations, local tensions within the Alexandrian society always expressed, over centuries and circumstances, the constant debate dominated by the social and intellectual elite on the place of violence in public space. Urban unrest, whether caused by Hellenistic crowds, Roman tyrants or Christian hierarchs, was always condemned by historians of Antiquity. In fact, none of these privileged authors ever contested the need to maintain social inequalities, defend political hierarchy, protect properties of the possessing and ruling class, to the point that popular violence was exploited by both elite and historians to defend or restore order. Ptolemaic princesses and officers of the royal guard in the Hellenistic period, distinguished members of the Greek community in the High Roman Empire, bishops and pagan leaders in late Antiquity, stirred up crowds and encouraged a targeted and punctual violence to defend their preeminence or reestablish their own authority. For their part, Greek and Roman historians referred to urban violence as a criterion for denouncing the populace who used it and above all the leaders who commissioned it. Throughout ancient historiography, it was common to denounce the dangerousness and versatility of lower class people, but in this history, written by the elite for the elite and about the elite, recording urban violence provided first of all a moral platform for denouncing bad rulers and inciting contemporary rulers to make limited use of it, lest they too might not sink into tyranny and opprobrium forever. 